\title{
Notes
}

\section{Evolving Conceptualizations of Property: A Proposal to De-Commercialize the Value of Fetal Tissue}

\author{
Nancy E. Field
}

Recent scientific developments that have dramatically increased the value of human tissue are raising unprecedented issues with respect to commercial property rights in the human body. These issues have led one court to recognize explicitly a person's commercial interest in his bodily tissue. $^{1}$ The ramifications of this decision in the area of fetal tissue research $^{2}$ are considerable, given the substantial research value of fetal tissue and the profound ethical issues associated with abortion. The decision, by lending support to the proposition that a woman may assert a commercial interest in her fetal tissue, critically underscores the imperative of effective laws to prevent the commercial exploitation of abortion.

The commercial value of fetal tissue stems from its unique and highly beneficial properties in medical research. ${ }^{3}$ The primary applications of fe-

1. See Moore v. Regents of the Univ. of Cal., 202 Cal. App. 3d 1230, 249 Cal. Rptr. 494 (1988); see also infra notes 51-52 and accompanying text. For a scholarly examination of how traditional property doctrine may be applied to find a commercial interest in bodily tissues, see generally Note, Touard the Right of Commerciality: Recognizing Property Rights in the Commercial Value of Human Tissue, 34 UCLA L. REv. 207 (1986).

2. Fetal tissue research uses samples of tissue taken from fetuses deceased as a result of spontaneous or induced abortions. Association of American Medical Colleges, Summary: Fetal ReSEARCH AND FETAL Tissue Research 9 (1988).

3. "[I]n preventive medicine . . . there is generally no practical substitute for the fetal tissues used. This is especially the case in the field of virology... . [In this field] it seems probable that the use of fetal tissues will offer the only chance for growing the viruses thought to cause hepatitis and infantile gastroenteritis." DEPARTMENT OF HeAlTH aND SOCIAL SECURITY, SCOTTISH Home AND Health Department, The Use of Fetuses and Fetal Material for Research: Report of 
tal tissue research are in therapeutic transplants of fetal tissue ${ }^{4}$ and the development of cell lines. ${ }^{5}$ Fetal tissue research may also enhance understanding of growth regulation as it relates to cancer and to the aging process, and will be important in preventing and treating genetic disease. ${ }^{6}$ Offsetting the vast scientific benefits of fetal tissue research, however, is the ethical risk that the increased demand for fetal tissue might promote abortions for profit. Assuming that women have alienable property interests in their fetal tissue, the introduction of pecuniary inducements to procure such tissue might cause some women to abort their fetuses rather than carry them to term. ${ }^{7}$

Although the scientific community and legislators have made piecemeal efforts to address the ethical concerns stemming from the possible sale of fetal tissue, the current regulatory regime still leaves several loopholes through which abortions for profit might occur. In addition to the possibility of selling fetal tissue outright to clinics and research establishments that perform abortions but are not subject to restrictive regulations, women who donate fetal tissue for research may have an interest in any commercial developments stemming from that research. ${ }^{8}$ Women may thus be able to obtain immediate payment for their fetuses and/or contractual agreements guaranteeing them royalties from any profits derived from eventual commercial applications of the research.

Part I of this Note examines existing law that recognizes in individuals property rights in their bodily tissues, and explores how this law pertains to the fetus. It argues that juridically, the status of the fetus is indistinguishable from that of other bodily tissues. It then discusses, and points out the limitations of, existing federal and state regulations and other ini-

The Advisory Group 2-3 (1972), reprinted in National Commission for the Protection of Human Subjects of Biomedical and Behavioral Research, ApPendix to RePort and RecOMMENDATIONS: RESEARCH ON THE FETUS, DHEW Pub. No. (OS) 76-128, at 19-3 (1975) [hereinafter APPEndix].

4. Fetal tissue is amenable to transplantation because it grows rapidly in the adult body yet tends not to be rejected by the immune system. Scientists have been investigating the use of fetal tissue transplants in the treatment of a wide range of conditions, including: Diabetes, Parkinson's Disease, and blood diseases such as sickle cell anemia, thalassemia and severe combined immunodeficiency. Association of American Medical Colleges, supra note 2, at 10-11.

5. Id. at 9 . A cell line is a sample of cells that has undergone the process of adaptation to artificial laboratory cultivation and is capable of sustaining continuous, indefinite growth in culture. "Cell lines prepared from human tissues are essential for the reproduction of human viruses both for the diagnosis of disease and in the production of human vaccines." Id. Cell lines from fetal tissue possessing rare genetic traits may also be cultivated for use in the manufacture of therapeutic drugs.

6. APpendix, supra note 3, at 1-35.

7. The offering of financial consideration for fetal tissues was documented in a 1977 report by the London Times. The article reported the sale by a South Korean medical practitioner of thousands of pairs of fetal kidneys to an American medical supply corporation. According to the report, the kidneys, which were in great demand as a medium for developing cultures, were resold in the United States to research laboratories conducting research aimed at producing antiviral vaccines. The report also mentioned that fetal material was being provided by approximately 250 sources in twelve countries. The Times (London), Mar. 13, 1977, at 10, col. 1.

8. See infra text accompanying notes 50-76 (discussing commercial property interest in human tissue). 
tiatives that attempt to prohibit the sale of fetuses and fetal tissue. Part II presents a legal argument, derived from general principles of property law, that women might use to assert a commercial property interest in their fetuses. Part III argues that judicial recognition of a commercial property interest in fetal tissue would be contrary to public policy, and Part IV concludes by proposing legislation that would provide a more effective bar against the exploitation of commercial property interests in fetal tissue for private profit.

\section{The Status of the Fetus in Property Law}

At least one court has recognized that, in the absence of restrictive legislation, a person has both a possessory and a commercial interest in her bodily tissues. ${ }^{9}$ Restrictive legislation-whether enacted in the form of direct prohibitions of sales or in the form of limitations of rights incidental to property interests-is not uncommon and reflects the belief that public policy concerns sometimes outweigh the benefits of unfettered property rights. Donors of human organs for transplant, for example, must comply with legislation prohibiting the offer or receipt of any financial consideration for organ transfers. ${ }^{10}$ The policy rationale behind these prohibitions stems from the paternalistic view that impoverished individuals might be induced to sell their organs for profit. Unlike donations of blood, which rarely cause adverse health effects since blood is replenishable, the removal of certain organs may be detrimental to human health. Legislators have perceived these public health risks as outweighing the value of an individual's unfettered right to sell his bodily organs. The policy argument for prohibiting the sale of fetal tissue-prevention of abortion for profit-is similarly viewed as outweighing unfettered property rights. However, although several policy-making institutions have addressed the issue of fetal tissue sales, the regulatory framework surrounding such sales has been very weak. ${ }^{11}$ Assuming that judicial decisions recognizing a property interest in human bodily tissue can be extended to include fetuses, and that women consequently can exploit this commercial property interest, the absence of effective legislative restrictions may allow the specter of abortions for profit to become a reality.

9. See Moore v. Regents of the Univ. of Cal., 202 Cal. App. 3d 1230, 1244-52, 249 Cal. Rptr. 494, 503-09 (1988) (court acknowledged "giving patients a financial interest in their tissues").

10. See infra notes 39-40 and accompanying text. For a discussion of arguments in favor of paying donors or their estates in order to increase the supply of organs available for transplant, see Posner, Utilitarianism, Economics, and Legal Theory, 8 J. Legal. Stud. 103, 138-39 (1979); Note, The Sale of Human Body Parts, 72 Mich. L. Rev. 1182, 1216-20 (1974); Trucco, Sales of Kidneys Prompt New Lau's and Debate, N.Y. Times, Aug. 1, 1989, at C1, col. 1.

11. See infra notes $23-49$ and accompanying text. 


\section{A. The Juridical Status of the Fetus: The Absence of Legal Distinctions Between Fetal and Other Bodily Tissue}

A uniform and absolute legal distinction between fetal and other bodily tissues does not presently exist. ${ }^{12}$ If such a distinction did exist, and the fetus were juridically recognized as a person, the law vesting in individuals a commercial interest in their bodily tissues would clearly not pertain to a woman's interest in her fetus. Sales of fetal tissue, in such a case, would fall within the jurisdiction of laws prohibiting the sale of babies. This section will demonstrate, however, that sweeping judicial precedent has not been established to accord fetal tissue a status distinct from any other bodily tissues.

The earliest and most frequently cited case discussing the legal status of the fetus, Dietrich v. Northampton, ${ }^{13}$ held that a child en ventre sa mere (in the womb of its mother) is an integral part of its mother, with no separate juridical existence, and therefore is not entitled to sue through an administrator for injuries causing its death. Although Dietrich was widely followed for many years, the interpretive trend since 1946 has been to exclude viable fetuses from its holding. Thus, injuries to viable ${ }^{14}$ fetuses are generally held compensable in tort actions brought after birth, ${ }^{15}$ and injuries to viable fetuses leading to death are generally remediable by a wrongful death action brought by the fetus' personal representative. ${ }^{16}$

Many courts have also extended rights of recovery to pre-viable fetuses.

12. In Webster v. Reproductive Health Services, 109 S. Ct. 3040 (1989), the Supreme Court was asked to rule on the constitutionality of the preamble, inter alia, to a Missouri statute regulating the performance of abortions. The preamble contained "findings" by the state legislature that "[t]he life of each human being begins at conception," and that "unborn children have protectable interests in life, health, and well-being." Id. at 3049 (quoting Mo. Rev. STAT. \$1.205.1(1),(2) (1986)). The Court, however, declined to rule on the constitutionality of the preamble on the grounds that it was merely an abstract proposition that as yet had not been applied. Id. at 3050 .

13. 138 Mass. 14 (1884) (no right of action can accrue to unborn fetus).

14. A viable fetus is one potentially able to live outside the mother's womb, albeit with artifical aid. Although viability is now generally thought to occur at about the twenty-fourth week of pregnancy, new developments in medical research presage the advancement of viability to a much earlier stage of pregnancy. See Akron v. Akron Center for Reproductive Health, 462 U.S. 416, 458 (1983) (O'Connor, J., dissenting). But see Kolata, Survival of the Fetus: A Barrier is Reached, N.Y. Times, Apr. 18, 1989, at C1, col. 4.

15. See Allaire v. St. Luke's Hosp., 184 Ill. 359, 368-74, 56 N.E. 638, 640-42 (1900) (Boggs, J., dissenting) (case frequently cited for well-reasoned dissenting opinion that child has right of action for injuries suffered in utero after point of viability); Amann v. Faidy, 415 Ill. 422, 114 N.E.2d 412 (1953) (overruling Allaire); see also Bonbrest v. Kotz, 65 F. Supp. 138, 141-42 (D.D.C. 1946) (first case recognizing cause of action by child for injuries suffered in utero after viability).

16. See, e.g., Verkennes v. Corniea, 229 Minn. 365, 38 N.W.2d 838 (1949) (under state's wrongful death statute, right of action found to exist for stillborn fetus that had attained developmental stage of viability). Cases finding a cause of action in wrongful death for a viable fetus often hinge on statutory interpretation of the word "person" as used in wrongful death statutes, rather than whether the fetus is a person in the philosophical, theological or scientific sense. See, e.g., Wallace v. Wallace, 120 N.H. $675,678,421$ A.2d 134, 136 (1980) ("Regardless of the philosophical, theological or medical theories of when life begins, we are dealing here with legal causes of action created by legislative act . . .."); Presley v. Newport Hosp., 117 R.I. 177, 192-93, 365 A.2d 748, 756 (1976) (construing meaning of "person" in wrongful death statute to include stillborn viable fetus). 
These rights, however, generally appear to be contingent upon live birth ${ }^{17}$ and as such reflect nothing more than a public policy interest in postnatal life. ${ }^{18}$ Moreover, the cases discussing the termination of fetal rights at prenatal death specifically declare that a pre-viable fetus after its death no longer has recognizable legal rights independent of its mother. ${ }^{18}$ From this suggestion, one may infer that a legally aborted pre-viable fetus is legally indistinguishable from any surgically removed bodily tissues. ${ }^{20}$ This is not to say that a pre-viable fetus is not distinguishable from other bodily tissues in other respects, whether biological, theological or philosophical; but rather, that from a legal perspective, once a pre-viable fetus is dead, it possesses no rights and is not recognized by the courts as a juridical entity. ${ }^{21}$ The case law allowing recovery where injuries are sustained and

17. See Danos v. St. Pierre, 402 So. 2d 633, 635 (La. 1981) ("From the moment of conception, a child is considered in law as if it had already been born, and is entitled to certain rights and privileges. However, this reputed legal personality is conditioned upon the child's live birth; if the child is not born alive, the effects of its fictional legal personality are considered never to have existed.") (interpreting legislative pronouncement that human being exists from moment of fertilization and implantation); Wascom v. American Indem. Corp., 348 So. 2d 128, 130 (La. App. 1977) ("Children born dead are considered as if they had never been born or conceived.") (quoting LA. Crv. CoDE ANN. art. 28 (West 1952)); Youman v. McConnell \& McConnell, Inc., 7 La. App. 315, 317 (1927) (child born dead never acquired "a legal personality distinct from its mother"); Wallace v. Wallace, 120 N.H. 675, 677, 421 A.2d 134, 135 (1980) ("IA]t common law, the existence of a child en ventre sa mere was recognized for some purposes . . . . [However,] [a]ll such rights terminated if the fetus aborted or was stillborn."); Endresz v. Friedberg, 24 N.Y.2d 478, 485, 248 N.E.2d 901, 904, 301 N.Y.S.2d 65, 70 (1969) ("[E]ven if, as science and theology teach, the child begins a separate 'life" from the moment of conception, it is clear that ... the law has never considered the unborn foetus as having a separate 'juridical existence' . . . or a legal personality or identity 'until it sees the light of day' "); Presley v. Newport Hosp., 117 R.I. 177, 197, 365 A.2d 748, 758 (1976) (Kelleher, J., dissenting) (although fetus in utero considered life in being for purpose of inheritance and fetus to some extent protected by the criminal laws, once stillborn, it loses those rights; universally recognized that enjoyment of rights of unborn contingent on being born alive); West v. McCoy, 233 S.C. 369, 375, 105 S.E.2d 88, 91 (1958) ("The policy considerations which call for a right of action when a child survives do not necessarily apply in absence of survival."); Hogan v. McDaniel, 204 Tenn. 235, 243, 319 S.W.2d 221, 224 (1958) ("[T]hat life begins at the moment of conception, and that it is such a vital organism as to be at once a person in esse ... is a pure fiction of the law. . . [The fetus] is a part of its own mother's physical body.").

18. Courts have extended recovery rights to pre-viable fetuses largely in recognition of the right to begin life unimpaired, regardless of the stage of development at which a cause of impairment might occur. As one commentator has explained, " $t$ ] he lack of a 'person' in being to whom the duty of care may be owed has often troubled courts, though it should not in cases where the child is later born alive and suffers after birth the results of the injury." 2 F. HARPER \& F. JAMEs, THE LAw OF TORTs 1029 (1956). Similar considerations govern the rights of a pre-viable fetus to inherit subject to survival. See 1 W. Blackstone, Commentaries *130.

19. See supra cases cited at note 17 .

20. However, one court that specifically declined to comment on the fetus" "personhood," either in the philosophical or scientific sense, held "as a matter of law, that a fetus is not relegated to the status of chattel." Witty v. American Gen. Capital Distribs., Inc., 727 S.W.2d 503, 506 (Tex. 1987). But see id. at 509 n.1 (Kilgarlin, J., dissenting) ("The court leaves us in a vacuum as how to identify a fetus.").

21. "As a general rule, an action for the wrongful death of an unborn child will not lie where the child had not sufficiently developed in its mother's body so that it could have lived apart from its mother at the time of injury." 62 AM. JuR. 2D Prenatal Injuries $\$ 17$ (1972). But see Porter v. Lassiter, 91 Ga. App. 712, 716, 87 S.E.2d 100, 103 (1955) (action permitted where fetus not viable but "quick," that is, capable of moving or stirring in its mother's womb). In a minority of states, courts will not grant a wrongful death action for either a viable or a nonviable fetus, due to their interpretation of "person" in wrongful death statutes. 
the fetus is consequently killed embraces this view: "the law focuses on the existence of the fetus as a physical part of the pregnant woman by emphasizing that compensation is being granted for injury incurred by the woman"22 rather than by the fetus.

Based on the foregoing, courts in some jurisdictions could reasonably conclude that there exists no legal distinction between a pre-viable aborted fetus and other tissues removed from a person's body. In such jurisdictions, the common law recognizing or conferring on individuals a commercial property interest in their bodily tissues would presumably encompass fetal tissue as well.

\section{B. The Regulatory Status of the Fetus}

\section{Federal Initiatives}

The unresolved issue of whether a fetus is a separate person or a part of its mother's bodily tissue, together with vigorous protest over the possible legality of fetal tissue sales, ${ }^{23}$ has prompted reactions in both the executive and legislative branches of the Federal Government. ${ }^{24}$ In 1974, Congress created the National Commission for the Protection of Human Subjects of Biomedical and Behavioral Research ("Commission"), mandated to "investigat[e] and study . . . research involving living fetuses, [and] ... recommend ... policies defining the circumstances (if any) under which such research may be conducted or supported."25 The Commission's recommendations formed the basis for federal regulations enacted in 1975 which, inter alia, state that "[n]o inducements, monetary or otherwise, may be offered to terminate pregnancy for purposes of . . . [research] activity." ${ }^{26}$ The regulations, however, are limited in that they explicitly govern only research funded by the Department of Health and Human Services (HHS) ${ }^{27}$ Furthermore, the regulations do not expressly

22. Note, Of Woman's First Disobedience: Forsaking a Duty of Care to Her Fetus-Is This a Mother's Crime? 53 BrookLyN L. REv. 807, 815 (1987).

23. Much of this concern was precipitated by the Supreme Court's decision in Roe v. Wade, 410 U.S. 113 (1973), and the expectation that an abundance of fetuses would thereafter become vulnerable to exploitation and commercialization.

24. A great deal of scholarly commentary has also been written on the subject. See, e.g., Baron, Legislative Regulation of Fetal Experimentation: On Negotiating Compromise in Situations of Ethical Pluralism, in Generics AND THE LAw III, at 431 (A. Milunsky \& G. Annas eds. 1984); Mahowald, Silver \& Ratcheson, The Ethical Options in Transplanting Fetal Tissue, 17 Hastings CENTER ReP. 9 (Feb. 1987).

25. National Research Act, Pub. L. No. 93-348, § 202(b), 88 Stat. 348, 350 (1974).

26. Protection of Human Subjects, 45 C.F.R. $\$ 46.206(\mathrm{~b})$ (1988).

27. Despite this explicit limitation, the federal regulations effectively cover all federally funded institutions, regardless of the source of the funds the institution may be using specifically for fetal research. See Baron, supra note 24, at 432-33. But see Consultants TO THE Advisory Committee to the Director, National Institutes of Health, 2 Report of the Human Fetal. Tissue Transplantation Research Panel, at D69 (Dec. 1988) (hereinafter Research Panel REPORT] (testimony of Arthur L. Caplan, Director of Center for Biomedical Ethics at University of Minnesota) ("A large proportion of the fetal tissues currently being used in research are procured by individual researchers through private arrangements they have made with obstetricians or abortion 
prohibit sales of fetal tissue and defer completely to state and local laws whenever research involves a deceased fetus or its tissue. ${ }^{28}$

More recently, public concern over the ethical implications of fetal tissue research and experimentation has increased, and the adequacy of existing regulations has been questioned. One observer has suggested that the increased public concern is due to:

fears that the demand from potential transplant recipients, possibly numbering in the millions, will be so urgent that human fetuses will be conceived and intentionally aborted so that their organs and tissues can be harvested for transplantation. . . . A more meaningful ethical concern regarding fetal tissue transplantations has to do with whether their therapeutic benefits would lend an implicit legitimacy to abortion that it does not now have. ${ }^{28}$

Increased public concern over the ethical implications of fetal tissue research manifested itself in March, 1988, when HHS imposed a moratorium on the use by the National Institutes of Health (NIH) of human fetal tissue obtained from induced abortions for therapeutic transplantations. ${ }^{30}$ In addition, in September, 1988, the White House issued a draft executive order that sought to proscribe research and experimentation involving fetuses from induced abortions and "to prohibit the commercial use or sale of an unborn . . . child's body, organ or tissue." ${ }^{\text {"31 }}$ Such an executive order, by its terms, would have affected all federal agencies and departments, facilities receiving federal funding, and facilities governed by federal law, ${ }^{32}$ had it taken effect.

Notwithstanding these efforts to curtail fetal tissue research, an expert panel convened under the auspices of NIH to examine the ethical, legal, and scientific issues of using human fetal tissue from induced abortions for research and therapy recommended continued utilization of fetal tissue. The panel stated in its draft recommendations to an NIH advisory committee that the use of fetal tissue from a legal, induced abortion "is acceptable public policy" because the research is aimed at significant medical

clinics.").

28. 45 C.F.R. $§ 46.210$ (1988) ("Activities involving the dead fetus, mascerated fetal material, or cells, tissue, or organs excised from a dead fetus shall be conducted only in accordance with any applicable State or local laws regarding such activities.").

29. Research PANel RePort, supra note 27, at E22-23 (testimony of Myron Genel, Associate Dean for Government and Community Affairs, Yale University School of Medicine (representing the Association of American Medical Colleges (AAMC) and the Association of American Universities (AAU))).

30. See Federal Agency Bars Implanting of Fetal Tissue, N.Y. Times, Apr. 16, 1988, at 1, col. 5. A recent report suggests that the Bush Administration plans to extend this moratorium. See Abortion Debate Clouds Research on Fetal Tissue, N.Y. Times, Oct. 16, 1989, at A19, col. 1.

31. Exec. Order Draft, §§ 4-5 (enclosure with letter from Gary Bauer, Assistant to President for Policy and Development, to Otis R. Bowen, Secretary of HHS, Sept. 2, 1988) (on file with author).

32. Id. at $\S 6$. 
goals. ${ }^{33}$ The panel nonetheless acknowledged "the moral convictions deeply held in our society"34 and concluded that "appropriate guidelines are required even as the research proceeds." 35

The draft recommendations of the panel, which were adopted by the advisory committee and proposed to NIH ("proposed guidelines"), attempt to balance the benefits of medical advancement against the risk of encouraging abortion by ensuring that abortion decisions not be predicated upon or induced by any information pertaining to the possible use of the fetus in medical research. The proposed guidelines, moreover, specifically embody the premise that the abortion decision should not be based on any financial inducement and, therefore, that no payments should be given to procure fetal tissue. ${ }^{36}$ The Yale-New Haven Medical Center has already adopted these guidelines in a research protocol. ${ }^{37}$ The Stanford University Medical Genter Committee on Ethics has also concluded that, subject to certain conditions, ethical considerations allow the appropriate medical use of human fetal tissue. ${ }^{38}$

Congress, for its part, has acted to minimize the ethical risks of fetal tissue research and experimentation by passing a recent amendment to the National Organ Transplant Act (NOTA) ${ }^{39}$ The amendment extends the provisions of the Act, which regulates organ transfer and prohibits the sale in interstate commerce of organs for transplant, to include specifically fetuses, fetal organs, and fetal tissues. The Act, however, limits the prohibition of fetal tissue sales to transactions involving transplants, and therefore does not reach the possibility of selling fetal tissue for the purpose of generalized research or for the commercial development of derivative products. ${ }^{40}$

33. 1 Research PANel RePort, supra note 27, at 1; see also Panel Again Backs Research With Tissue of Aborted Fetuses, N.Y. Times, Oct. 22, 1988, at 9, col. 2.

34. 1 Research Panel Report, supta note 27 , at 1.

35. Id.

36. See id.

37. Yale University School of Medicine, Yale-New Haven Hospital, Protocol for Research Involving Human Subjects (Apr. 18, 1988) [hereinafter Protocol] (on file with author). Under the Yale Protocol, women are not made aware of the possibility of being invited to participate in research until all arrangements for the abortion procedure, including the obtaining of informed consent, have been accomplished. The Protocol, moreover, states explicitly that there shall be no economic consideration for donors of fetal tissue. See infra note 54.

38. Special Report, The Ethical Use of Human Fetal Tissue in Medicine, 320 NEw ENG. J. MED. 1093 (1989). The report argues, as does this Note, for an expansion of legal constraints on the commercialization of fetal tissue.

39. Pub. L. No. 98-507, 98 Stat. 2339 (1984), amended by Title IV-Organ Transplant Amendments of 1988, Pub. L. No. 100-607, 102 Stat. 3116 (1988) (codified as amended at 42 U.S.C.A. $\S \S 273-274 \mathrm{e}$ (West Supp. 1989)).

40. Pub. L. No. 98-507, § 301(a), 98 Stat. 2339, 2346 (1984) ("It shall be unlawful for any person to knowingly acquire, receive, or otherwise transfer any human organ for valuable consideration for use in human transplantation if the transfer affects interstate commerce."), amended by Title IV-Organ Transplant Amendments of 1988, Pub. L. No. 100-607, § 407, 102 Stat. 3116 (1988) ("The term 'human organ' means the human (including fetal) kidney, liver, heart, lung, pancreas, bone marrow, cornea, eye, bone, and skin or any subpart thereof and any other human organ (or any subpart thereof, including that derived from a fetus) specified by the Secretary of Health and Human 


\section{State Legislation}

Various state statutes supplement the federal legislation governing fetal tissue sales. All fifty states and the District of Columbia have adopted the Uniform Anatomical Gift Act (UAGA), ${ }^{41}$ which governs gifts of tissues and organs for research or therapeutic transplants. The scope of UAGA, which was promulgated in 1968, reaches the procurement and use of tissue from deceased fetuses. ${ }^{42}$ The Act permits fetal tissue to be donated for research purposes if either parent grants permission and the other does not object. ${ }^{13}$ While twenty-five states rely exclusively, with respect to research on deceased fetuses, on the enabling provisions of UAGA, ${ }^{44}$ the remainder have specific statutes supplementing or preempting UAGA. Although some of these statutes expressly prohibit nontherapeutic research on deceased fetuses, ${ }^{45}$ the vast majority of regulating states permit it. ${ }^{46}$

The 1968 version of UAGA did not directly address the issue of selling bodily parts. However, a more recent version of the Act prohibits purchases and sales of bodily parts for valuable consideration where removal of the part is intended to occur after the death of the decedent. ${ }^{47}$ Although this provision appears to encompass sales of fetal tissue, it has, like NOTA, been narrowly drawn and applies only to transactions of bodily parts for transplantation or therapy, as opposed to generalized re-

Services by regulation.").

41. Unif. Anatomical Gift ACt, 8A U.L.A. 30 (1983).

42. " 'Decedent' means a deceased individual and includes a stillborn infant or fetus." $I d$. at $\S$ 1(b).

43. Id. at $\S \S 2(\mathrm{~b})-(\mathrm{c})$.

44. See Baron, Fetal Research: The Question in the States, 15 Hastings Center ReP. 12 (Apr. 1985).

45. See, e.g., ARIz. Rev. Stat. ANN. § 36-2302.A (1986):

A person shall not knowingly use any human fetus or embryo, living or dead, or any parts, organs or fluids of any such fetus or embryo resulting from an induced abortion in any manner for any medical experimentation or scientific or medical investigation purposes except as is strictly necessary to diagnose a disease or condition in the mother of the fetus or embryo and only if the abortion was performed because of such disease or condition.

See also IND. CODE ANN. § 35-1-58.5-6 (Burns 1985) (prohibiting experimentation other than pathological examinations on aborted fetus); OHIo REv. CODE ANN. \$2919.14 (Anderson 1987) (prohibiting experimentation upon or sale of "the product of human conception which is aborted."); OKLA. STAT. ANN. tit. 63, \$ 1-735.B (West 1984) (prohibiting experimentation "upon the remains of a child or an unborn child resulting from an abortion.").

46. Baron, supra note 44, at 14-15. Twenty-five states have no regulations governing fetal tissue research other than the enabling provisions of UAGA. Among the regulating states, Arkansas, California, Florida, Kentucky, Maine, Massachusetts, Michigan, Minnesota, Missouri, Montana, Nebraska, New Mexico, North Dakota, Pennsylvania, Rhode Island, South Dakota, Tennessee, Utah, and Wyoming permit research on deceased fetuses. The only states not permitting nontherapeutic research on deceased fetuses are: Arizona, Illinois, Indiana, Louisiana, Ohio, and Oklahoma.

47. Unif. ANatomical Gift Act (1987) § 10, 8A U.L.A. (Supp. 1989). California, Connecticut, and Hawaii have repealed the 1968 version of UAGA and have enacted instead the 1987 version. Connecticut, however, has not adopted the relevant section and only prohibits the acquisition, receipt, or other transfer for valuable consideration of human organs for use in human transplantation. See Conn. Gen. Stat. AnN. $\S 19 a-280$ a (West Supp. 1989). Hawaii has adopted the relevant section without modification, see HAw. REv. STAT. ANN. \$ 327-10 (1988), while California has adopted and expanded the relevant part, see Cal. Health \& SAfETY Code $\$ 7155$ (West Supp. 1989). 
search or product development. ${ }^{48}$ As for individual state statutes, most contain no express prohibitions against sales of fetal tissue. ${ }^{49}$

The uncertain juridical status of the fetus, coupled with a regulatory framework that has not anticipated the potential for commercial trade in fetal tissue, has created an environment conducive to the commercial exploitation of fetal tissue. The following section demonstrates that current case law, which explicitly acknowledges an individual's property right in her bodily tissue, could be extended to the fetus unless courts clearly distinguish the fetus from other bodily tissues, or restrictive legislation is promulgated expressly prohibiting the free exercise of commercial property rights in fetal tissue.

\section{The Emerging Property Right in Fetal Tissue}

As discussed in Part I, existing federal rules governing fetal tissue research contain inadequate restrictions on sales and, moreover, govern only federally funded research establishments. Of the additional sources of law governing fetal tissue sales, NOTA applies only in the narrow context of transplantation and the 1987 version of UAGA, which has been adopted in relevant part by only two states, applies only in the context of transplantation or therapy. The law therefore leaves open the potential for exploitation of commercial property rights in fetal tissue and the development of a market in such tissue. These gaps in the existing regulatory framework have assumed new significance in light of a recent decision, Moore v. Regents of the University of California, ${ }^{\text {so }}$ by a California court of appeal.

\section{A. The Moore Opinion}

Moore held that a person possesses a commercial property interest in his bodily tissue. ${ }^{51}$ The case arose when a patient, who had been hospital-

48. UNIF. ANatomical Gift Act (1987) § 10, 8A U.L.A. (Supp. 1989). But see Cal. Health \& SAFETY CODE $\$ 7155$ (West Supp. 1989) (expanding relevant section to prohibit sales "for transplantation, therapy, or reconditioning").

49. For examples of state Anatomical Gift Acts that do prohibit sales of fetal tissue, see ILL. ANN. STAT. ch. 11, para. 308.1 (Smith-Hurd Supp. 1989) (any payment or offer of payment of any financial consideration to donor considered misdemeanor for first conviction and felony for subsequent convictions); N.M. STAT. ANN. § 24-6-11.A (Supp. 1988) ("No person may acquire, receive or otherwise transfer for valuable consideration any human organ or tissue."); N.Y. PUB. HeALTH LAw $\S$ 4307 (McKinney 1985) ("It shall be unlawful for any person to knowingly acquire, receive, or otherwise transfer for valuable consideration any human organ for use in human transplantation."); VA. CODE ANN. \$ 32.1-289.1 (1985) ("With the exception of hair, blood and other self-replicating body fluids, it shall be unlawful for any person to sell, to offer to sell, to buy, to offer to buy or to procure through purchase any natural body part for any reason including, but not limited to, medical and scientific uses such as transplantation, implantation, infusion or injection.").

50. 202 Cal. App. 3d 1230, 249 Cal. Rptr. 494, review granted, 763 P.2d 479, 252 Cal. Rptr. 816 (1988).

51. The explicit holding in Moore was that the commercial exploitation of bodily tissues without fully informed consent constitutes a conversion. In so holding, however, the court recognized by implication that people have a "financial interest in their tissues." See 202 Cal. App. 3d at 1252, 249 Cal. 
ized for a common surgical procedure, discovered that research scientists had used his blood to develop a cell line from which profitable pharmaceutical products were manufactured. Although the patient had consented to the use of his blood in research, he never expressly consented to any commercial use of his blood. The court held that, absent express knowledge and informed consent, such commercial rights could not be waived. ${ }^{52}$ Although the court did not determine how compensatory damages would be valued, it ruled that the plaintiff was entitled to recover some share of the profits derived from the commercial use of his bodily tissue.

In the absence of judicial authority establishing a legal distinction between fetal and other bodily tissues, the holding in Moore could be interpreted to include fetal tissue. ${ }^{\mathrm{53}}$ Given the prohibition against donor compensation embodied in the draft NIH guidelines for fetal tissue research, ${ }^{54}$ and Moore's requirement that waivers of donors' rights to compensation for commercial exploitation of bodily tissue be explicit and predicated on fully informed consent, institutions adhering to the NIH guidelines would be required to change their informed consent procedures to fully reconcile the NIH guidelines with Moore. These institutions would presumably respond by amending consent forms ${ }^{\mathrm{ss}}$ to inform patients of possible commercial applications of fetal tissue research and to obtain specific waivers of any commercial rights attendant on such research. ${ }^{\text {s6 }}$ Consequently,

Rptr. at 509.

52. "If it should develop that plaintiff did expressly consent to what took place . . . plaintiff will have no basis for . . . [his] claim . . . . We conclude, however, that simple consent to surgery does not imply a consent to . . . commercial exploitation of the patient's tissues." Id. at 1254, 249 Cal. Rptr. at 510 .

53. It is conceivable, however, that a court considering the application of the Moore doctrine to a case involving fetal tissue might rely on the NIH guidelines as an indicator of public policy to distinguish fetal tissue from other bodily tissues. The Moore court stated that it "[had] been cited to no legal authority, public policy, nor universally known facts of biological science concerning the particular tissues referred to in th[e] pleading . . . which compel a conclusion that th[e] plaintiff cannot have a sufficient legal interest in his own bodily tissues amounting to personal property." Id. at 1244,249 Cal. Rptr. at 503-04. The NIH guidelines, however, despite their value as an indicator of federal public policy, do not represent legal authority binding on courts. Thus, a court might be inclined, in light of the persuasive authority which can be advanced in favor of a commercial property interest in all human (including fetal) tissues, to follow Moore in the absence of statutory direction to the contrary.

54. The Yale Protocol, for example, states in its present form that there shall be no economic consideration for donors of fetal tissue and "[n]o commercialization, payments, or incentives to donate the fetal tissue ...." Protocol, supra note 37, app.G at 16. This stipulation appears to cover not only direct payments but also contracts for a share of future profits derived from fetal tissue research.

55. Standard consent forms authorize hospitals to dispose of or preserve fetal tissue or other bodily parts for diagnostic, scientific or teaching purposes, in accordance with medical practice. The Moore holding "will require hospitals and surgeons to give prospective patients an expanded advisement concerning potential research and commercial use of their removed bodily tissue and fluid or otherwise risk foregoing such use or incurring potential liability." 202 Cal. App. 3d at 1266-67, 249 Cal. Rptr. at 536 (George, J., dissenting).

56. However, regulations for the protection of human research subjects appear to prohibit all waivers of subjects' legal rights. 45 C.F.R. $\$ 46.116$ (1988) ("No informed consent, whether oral or written, may include any exculpatory language through which the subject or the representative is made to waive or appear to waive any of the subject's legal rights . . .".). This would presumably include the right, recognized in Moore, to participate in profits from commercialization of bodily 
women seeking compensation, rather than altruistically donating their tissue for research, would choose to avoid clinics and hospitals receiving $\mathrm{NIH}$ or other federal funds and would seek out unregulated abortion clinics that do not adhere to the guidelines. In such establishments, women could receive direct compensation for use of their fetal tissue or could demand contractual agreements with physicians or research scientists for profit-sharing in the event that fetal tissue research should lead to commercial applications. ${ }^{57}$ Although many potential donors of fetal tissue might be willing to waive their rights to financial compensation, it is conceivable that a significant number would opt for some form of remuneration, thereby circumventing the policies embodied in the NIH guidelines.

\section{B. Possessory Rights to Fetal Tissue: The Moore Analysis}

The Moore court's determination that a person has a commercial property interest in her bodily tissues stemmed from its recognition of a full possessory right to such tissues. The court was not making the "legislative" decision whether the use of human tissue or body parts as raw material for commercial developments should be limited to gifts or should be subject only to the constraints of a free market. ${ }^{58}$ Rather, the court predicated its decision that an individual has a commercial interest in his tissues upon an individual's uncontroverted possessory interest in those tissues. The court asserted that, given the degree of control that an individual may exercise over his bodily tissues, the taking of such tissues for commercial use without that person's fully informed consent constitutes a conversion in the absence of a legislative ruling to the contrary.

Although the Moore court stated that it was neither called upon nor was it attempting "to resolve the complex issues relating to the human fetus," ${ }^{\prime 68}$ its analysis, when applied to fetal tissue, strongly supports the conclusion that women have similar legal protections against the conversion of fetal tissue. In particular, in those jurisdictions where fetal tissue is described as the possessory property of women carrying it and is vested with the same characteristics of property as the tissue in Moore, it should logically be subject to the same legal findings as the bodily tissue dealt with in the Moore decision.

tissues. These regulations apply to research conducted or funded by HHS, and appear to be in direct conflict with the NIH guidelines prohibiting donor compensation.

57. See Hardiman, Toward the Right of Commerciality: Recognizing Property Rights in the Commercial Value of Human Tissue, 34 UCLA L. REv. 207, 232 (1986) ("Recognition of the patient's property rights ... requir[es] the physician to negotiate in advance or to engage in bargaining once the commercial value of the patient's tissue becomes apparent.").

58. "We are not called on to determine whether use of human tissue or body parts ought to be 'gift based' or subject to a "free market." 202 Cal. App. 3d at 1244, 249 Cal. Rptr. at 504. The primary example of a "gift based" statute is UAGA, which provides for "donations" of organs and tissues from deceased persons and fetuses. See supra notes $41-43$ and accompanying text.

59. 202 Cal. App. 3d at 1248 n.8, 249 Cal. Rptr. at 506 n.8. 
The Moore analysis is broad enough, moreover, to apply to fetal tissue. The court used, as a starting point, the "broadest and most extensive"60 definition of property, stating that property is that collection of rights amounting to the unrestricted "use, enjoyment and disposition" of an object. ${ }^{61}$ Because property interests "are created, and their dimensions are defined, by existing rules or understandings that stem from an independent source such as state law, ${ }^{, 62}$ any inquiry into the legal status of the fetus and fetal tissue based on property rights must consider not only the common law, but also the law embodied in state statutes governing the various components of a property interest in the fetus. Given the definition of property relied on in Moore and accepted by legal scholars, ${ }^{63}$ property interests established by state laws can be analyzed in two parts: the right to use and enjoyment of an object, and the right of disposition of that object.

\section{Right to Use and Enjoyment}

The right to the use and enjoyment of an object is an element essential to a recognizable property interest. With respect to in utero fetuses, the concept of use and enjoyment may be best understood in terms of the right of women to autonomous choices of lifestyle, regardless of the impact that those choices might have on their fetuses. This right has been recognized in the context of prenatal abuse law. While courts in many states recognize causes of action brought against third parties for injuries to previable fetuses subsequently born with defects, ${ }^{\text {ex }}$ they almost uniformly reject actions brought against women for prenatal abuse of their own fetuses. To date, very few courts have allowed a child to recover against its mother for negligent infliction of prenatal injuries. ${ }^{65}$ The special status of women with respect to the treatment of their fetuses reflects an existing recognition by courts that women possess an unfettered right to use and enjoy their own bodily tissues, including that of their fetuses.

60. Id. at 1245,249 Cal. Rptr. at 505 (quoting 73 C.J.S. Property $\S 4$, at 163-64 (1983)).

61. Id. at 1245, 249 Cal. Rptr. at 504 (“As a matter of legal definition, 'property' refers not to a particular material object but to the right and interest or domination rightfully obtained over such object, with the unrestricted right to its use, enjoyment and disposition." (quoting 63A AM. JUR. 2D Property \& 1 (1984))).

62. 63A AM. Jur. 2D Property $\S 1$ (1984).

63. See R. Brown, The Law of Personal Property 6 (2d ed. 1955) ("[T]he right of property is . . . a collection or bundle of rights, of legally protected interests. The owner of a given piece of land or chattel has not only the interest of possession, and of enjoyment and use [], but also that of ... directing how it shall be disposed of . . . .") (emphasis added).

64. See 62 AM. JuR. 2D Prenatal Injuries $\$ 5$ (1972).

65. See e.g., Grodin v. Grodin, 102 Mich. App. 396, 301 N.W.2d 869 (1980); see also Johnsen, The Creation of Fetal Rights: Conflicts with Women's Constitutional Rights to Liberty, Privacy, and Equal Protection, 95 YALE L.J. 599, 605 (1986) ("The creation of fetal rights that can be used to the detriment of pregnant women is a very recent phenomenon, and thus far has occurred in only a relatively small number of cases."). However, at least one commentator predicts an increase in state intervention on behalf of fetuses, both through coerced medical treatment of pregnant women and through use of child custody provisions. See Johnsen, supra, at 605-09. 


\section{Right of Disposition}

In addition to the right to use and enjoyment, the right of disposition is also necessary to constitute a full possessory property right as defined by Moore. ${ }^{68}$ The right of disposition may itself be seen as comprised of two essential parts: (1) the right to dispose of the fetus by abortion; and (2) the right to determine whether or not the aborted fetus should be used for research purposes.

The Supreme Court's holding in Roe v. Wade ${ }^{67}$ implies a right of disposition until the end of the first trimester. Roe, though decided on the basis of a constitutional right to privacy, ${ }^{68}$ confers on the mother a de facto property interest in her fetus until the point of viability with respect to the right of abortion. More specifically, the Court in Roe, as subsequently modified by Webster v. Reproductive Health Services, held that prior to the end of the first trimester, the state may not interfere at all in the abortion decision, and subsequently, prior to viability, the state's regulation of abortion is strictly limited to laws that are reasonably related to the protection of maternal health. ${ }^{69}$

With respect to the more specific right to determine the use of the fetus in research, some states have conferred on women a statutory right to make such determinations. In South Dakota, for example, "[e]xperimentation with fetuses without written consent of the woman [is] prohibited,"70 and in Tennessee, "[i]t [is] unlawful for any person . . . to engage in medical experiments, research, or the taking of photographs upon an aborted fetus without the prior knowledge and consent of the mother." "11 At least twenty-five additional states adhere without modification to the UAGA guidelines which require the woman's consent. ${ }^{72}$ In other states, however, statutes accord little or no importance to maternal consent, ${ }^{73}$ prohibiting research on fetuses and fetal tissue entirely, regard-

66. The ultimate disposition of the aborted fetus is subject to regulation by public health statutes. However, "[s]ignificant limitations imposed by law on the disposition of a body after death reflect public health concerns, rather than a legislative policy against a property interest . . ." Moore, 202 Cal. App. 3d at 1247, 249 Cal. Rptr. at 505. "[T]he absence of unlimited or unrestricted dominion and control does not negate the existence of a property right for the purpose of a conversion action." Id. at 1248-49, 249 Cal. Rptr. at 506-07.

67. 410 U.S. 113 (1973).

68. Id. at 153-54 ("This right of privacy . . . is broad enough to encompass a woman's decision whether or not to terminate her pregnancy.... We, therefore, conclude that the right of personal privacy includes the abortion decision ....").

69. Id. at 163. In Webster, 109 S. Ct. 3040 (1989), the Court somewhat relaxed the "rigid line" demarcating viability, id. at 3057 , and held constitutional a state statute that requires testing towards the end of the second trimester (the twentieth week of pregnancy) to determine whether viability already exists. Although the Court implied a willingness to reconsider further the trimester framework in the future, it did not alter its jurisprudence with respect to the absolute right of abortion in the first trimester.

70. S.D. Codified LAwS ANN. \$ 34-23A-17 (1986).

71. TENN. CoDe ANN. \$ 39-4-208 (1982).

72. See Baron, supra note 44 , at 14 .

73. See id. But cf. Research Panel Report, supra note 27, at D73 (testimony of Arthur L. 
less of the woman's wishes. ${ }^{74}$ The federal regulations defer to state and local rules governing deceased fetuses and their tissues, ${ }^{75}$ although they do require the mother's consent for research performed on live, nonviable fetuses ex utero. ${ }^{76}$ In sum, although the right to determine whether the fetus shall be used in research does not exist uniformly, it has certainly been conferred in a substantial number of states.

Since Roe recognizes in all women the right to abort a pre-viable fetus, the additional element necessary to establish a right to "disposition" of the fetus may be found in those jurisdictions in which women also possess the right to permit or to disallow research on the aborted fetus. In such jurisdictions, women may be said to fulfill the criteria adopted in Moore for establishing a property interest in their fetuses: They possess both the right to use and enjoyment, as inferred from the lack of recourse against a woman's prenatal abuse of her fetus, and the right of disposition derived both from the holding in Roe v. Wade and from statutes conferring the power of veto over subsequent uses of aborted fetuses. Thus, the prospect that women may be able to receive consideration for their aborted fetuses, whether through lump-sum payments or through royalty interests in derivative products, is not remote in many jurisdictions and therefore deserves legislative attention.

\section{Public Policy Gonsiderations Governing Sales of Fetal Tissue}

Allowing women to sell their fetal tissue directly, or to exercise their right to share in profits resulting from commercial development of their fetal tissue, would be contrary to public ethics and policy. The primary ethical concern surrounding fetal tissue research has been the prospect of encouraging abortions for profit. With respect to direct sales for lump-sum

\footnotetext{
Caplan):

It should also be obvious that those who seek fetal tissue must be held accountable for obtaining full and informed consent from donors. A California court recently held that John Moore, a man who had had his spleen removed in order to treat his leukemia, has a property interest in cells that were grown from his spleen. Women who undergo abortions have the same right to information about what is to happen to fetal remains and to consent or not consent to the use of tissues for transplantation or other medical purposes.
}

74. See Wynn v. Scott, 449 F. Supp. 1302, 1322 (N.D. Ill.), appeal dismissed sub nom. Carey v. Wynn, 439 U.S. 8 (1978), affd, 599 F.2d 193 (7th Cir. 1979) (upholding provision of statute prohibiting research on aborted fetuses as valid exercise of state's police power to regulate health-related matters). But see Margaret S. v. Treen, 597 F. Supp. 636, 675 (E.D. La. 1984) (holding that Louisiana lacked legitimate state interest in proscribing research on dead fetuses, and pointing out inconsistency of statute which allowed, under Louisiana Anatomical Gift Act, donation by mother of body of her child to medical science), affd sub nom. Margaret S. v. Edwards, 794 F.2d 994 (5th Cir. 1986). Arizona, Illinois, Indiana, Louisiana, Ohio, and Oklahoma do not permit nontherapeutic research on dead fetuses if they are the product of a therapeutic abortion. Baron, supra note 44, at 14.

75. But see RESEARCH PANEL RePORT, supta note 27, at D151 (testimony of Robert J. Levine, M.D.) ("[T]he [Yale-New Haven Medical Center Institutional Review Board, which follows federal regulations and guidelines regarding fetal experimentation,] considers maternal consent sufficient authorization for the use for research purposes of the dead fetus, fetal material, or the placenta.").

76. 45 C.F.R. $\S 46.209$ (d) (1988). 
consideration, the guarantee of compensation for the fetus would provide an obvious incentive for women to undergo abortions. In the case where a woman is offered a royalty interest in potential commercial developments that utilize her fetal tissue, the realization of financial gain may be unlikely; however, the patient's knowledge that a profit might nevertheless accrue could encourage abortions in some borderline cases in which the ultimate decision might hinge on the additional financial incentive. Public policy as recently expressed through the NIH guidelines ${ }^{77}$ as well as in regulations governing federally funded research unequivocally opposes inducing women to conceive and abort for financial consideration. However, despite strong public policy to the contrary, the possibility that abortions for profit could occur nevertheless exists.

Even if no woman would deliberately abort her fetus for pecuniary gain, and abortion decisions remained wholly independent of financial inducements, the presence of market inducements might impinge upon the secondary decision whether or not to contribute fetal tissue to medical research. A commercial system of fetal tissue procurement might undermine the sense of social responsibility that often motivates donations and thereby diminish the availability of fetal tissue for research. ${ }^{78}$ Although public policy militates against the inducement of abortion to increase what is perceived as a low supply of fetal tissue for transplantation and research, ${ }^{79}$ it is equally contrary to public policy to dissuade donations of tissue once the abortion decision has been made. On a more philosophical level, allowing women to profit from research on their fetuses might introduce a sense of "commodification" into reproduction and pregnancy, and at some level undermine human dignity. ${ }^{80}$

Although recent attempts have been made by Congress and NIH to

77. See U.S. Congress, Office of Technology Assessment, New Developments in BioTeChNology: OWNership of Human Tissues and Cells-Special Report 96 (1987) ("NIH is the primary source of funding for biomedical research undertaken at medical schools, graduate science programs, and research hospitals ....").

78. Among the arguments against a market in body parts has been an expected decline in altruism. See The Hastings Center, Ethical, Legal and Policy Issues Pertaining to Solid Organ Procurement: A Report of the Project on Organ Transplation 2 (Oct. 1985) ("Altruism and a desire to benefit other members of the community are important moral reasons which motivate many to donate. Any perception ... [by] the public that transplantation . . . is undertaken primarily with an eye toward profit . . . will severely imperil the moral foundations, and thus the efficacy, of the [donative] system."); see also Manga, A Commercial Market for Organs? Why Not, in 1 BIoETHIcs 321, 328 (H. Kuhse \& P. Singer eds. 1987) (study comparing voluntary and commercial systems of procuring blood found voluntary systems more successful, demonstrating that "people can be highly motivated with a sense of social responsibility towards the urgent health care needs of their community in a voluntary system, and that promoting the selling of blood significantly reduced this sense of generosity and concern.").

79. If, for example, abortion-inducing drugs such as RU 486, a drug recently developed in France, become available in the United States, the availability of fetal tissue for research and transplantation might decline dramatically.

80. See Radin, Market-Inalienability, 100 HaRv. L. Rev. 1849, 1903-06 (1987) (monetization of personal attributes undermines human identity); Cf. Calabresi \& Melamed, Property Rules, Liability Rules, and Inalienability: One View of the Cathedral, 85 HARv. L. REv. 1089, 1111-12 (1972) (identifying moralisms as grounding for rules of inalienability). 
address these policy concerns, the extant laws have been narrowly drawn and do not begin to address all of the potential commercial aspects of fetal tissue research. Outside of those few states that explicitly prohibit all sales of fetal tissue and fetal parts, the prospect of commercial transactions infusing fetal tissue research remains very real. ${ }^{\mathbf{8 1}}$

\section{Legislative Proposal}

To achieve the policy goals of making fetal tissue available for medical research and therapy while avoiding any inducement of abortion for profit, this Note proposes the enactment of federal legislation prohibiting the offer, solicitation, giving, or receiving of any consideration in any transactions involving the transfer or procurement of fetal tissue. ${ }^{82}$ This legislation would apply not only to women having abortions but to any other person involved in the transfer or procurement of fetal tissue. The proposal would ensure that all acquisitions of fetal tissue by research institutions would occur strictly through donative transfers.

The legislation envisioned by this Note, moreover, would require that all fetal tissue research in the United States be conducted in federally licensed and regulated nonprofit research institutions. ${ }^{83}$ In such establishments, compensation would be paid to the research scientists for their services, and additional revenues flowing from the development of commercially valuable products would inure to the benefit of the nonprofit institution. ${ }^{84}$ By eliminating any potential for profit from the transfer of fetal tissue, the proposed legislation would help to prevent the exploitation of abortion and would thereby benefit society by allowing critically important medical research to continue while safeguarding public ethics and policy.

81. Commercial transactions may arise not only as a result of profit-sharing from derivative products but also, in many states, from outright sales of fetal tissue by women-or resales by doctors or hospitals-to companies conducting fetal tissue research. Commercial transactions in fetal tissue have already been documented. See supra note 7 .

82. Reasonable consideration would be allowed, however, for costs of delivery, storage, and retrieval of fetal tissue incurred in donative transfers.

83. It has already been suggested, in the context of federally funded research, that

the assurance section of the regulations-by which institutions interested in receiving federal funds agree to abide by HHS guidelines-could be amended to place a condition on federal funding providing that no employee of the institution may have a personal financial interest in the research. The regulations also could be amended to require that any profit from the research be deposited into the university's research accounts and applied for the benefit of persons like the subject or to further research into the condition described in the research protocol.

Delgado \& Leskovac, Informed Consent in Human Experimentation: Bridging the Gap Between Ethical Thought and Current Practice, 34 UCLA L. REv. 67, 126 (1986) (citations omitted). The proposal advanced in this Note would essentially expand the safeguards delineated above to ensure that the patient as well as the physicians, researchers, or any other party may not have any personal financial interest in the research, and to regulate all fetal tissue research, whether funded federally or otherwise.

84. The drafters of such legislation might, however, consider allowing joint ventures between federally licensed and regulated nonprofit institutions and for-profit firms in order to facilitate the processing and marketing of eventual products such as vaccines and therapeutic drugs. 


\section{Conclusion}

Under existing law, courts in a substantial number of jurisdictions could find that women have a right to profit from sales of their fetal tissue. In light of the considerable demand for fetal tissue in medical research and therapy, the existence of such a right might lead to abortions for profit. Public policy clearly opposes abortions for profit, and it is essential that laws are drawn to effectuate this policy. To prevent the development of a commercial market in fetal tissue and the dangerous infusion of commercial values into abortion decisions, federal legislation should be enacted prohibiting all commerce in fetal tissue and mandating that fetal tissue research be conducted exclusively on a not-for-profit basis by federally regulated research establishments. 